ISSN 1991- 8690

website : http:// jsci.utq.edu.iq
الترقيم الدولي 8690 - 1991

Email: utjsci@utq.edu.iq

\title{
Study of plasmid profile and susceptibility patterns of Escherichia coli isolated from patients with urinary tract infection in Basra
}

\section{$\underline{\text { Abstract }}$}

\author{
Maithem A.Al-Hamdani \\ Ismaal J.Abas \\ Dept.Biol.Coll.Educ. - University of Basra - Basr a, Iraq
}

The present study was designed to investigate plasmid profiles and the prevalence of multidrug resistant Escherichia coli, which was done in Basra, Iraq, during the period between September 2012 and January 2013. A total of 306 urine sample were collected and cultured from patients with UTI, only 137 sample give positive growth.72 isolates diagnosed as E.coli isolates and tested for antibiotic susceptibility ,high antibiotic resistance toAmpcillin 100\%,Cefazolin93.05\%,Augmentin $83.33 \%$,and Nitrofurantion70.83\%, mid resistance to Piperacillin62.5\%, Cefixime63.88\%, Kanamycin48.61\%, Cefepime43.05\%, , ceftriaxone40.27\%, , and Tobramycin36.11\%, low resistance to Cotrimoxazole25\%, Ciprofloxacin23.6\%, Nalidixic Acid23.6\% ,Aztreonam18.05\%, Norfloxacin15.27\%,Amikacin9.72\%,Gentamicin8.33\%, Chloramphenicol5.55\%, cefoxitin1.38\%, and Imipenen 0\% .E.coli isolates showed multiple antibiotic resistance .The MAR index of the isolated ranged between 0.2 and 0.8 . Most isolates harbor large molecular weight plasmids ranging from (1- >10) Kbp.

Key words: Escherichia coli, Plasmid profile, Urinary tract infection, antibiotic resistance

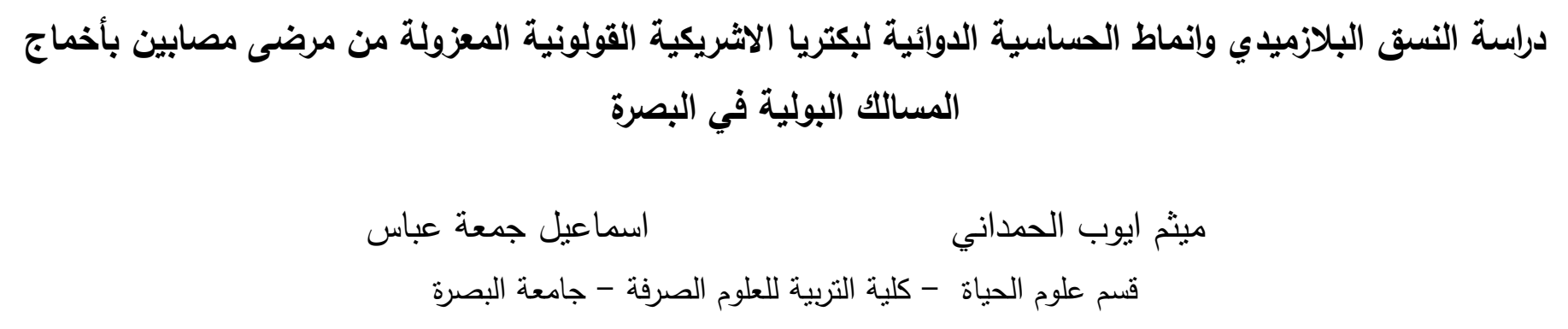

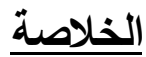

صمدت هذة الدراسة لكثف عن النسق البلازميدي وكنلك المقاومة الدتعددة لبكتريا الاثريكية القولونية. اجريت الدراسة في محافظة

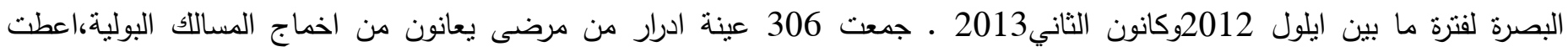
137عينة نمواً موجباً. 72 عزلة فقط شخصت على انها بكتريا الاشريكية القولونية اجريت لها اختبار الحساسية الدوائية بطريقة الانتثار

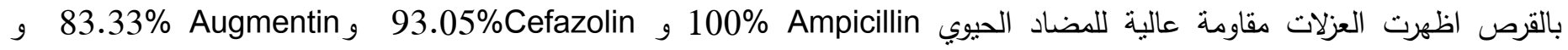
36.11\%Tobramycin,62.5\%Piperacillin, 43.05\%Cefepime, 70.83\% Nitrofurantion 25\%Cotrimoxazole, 63.88\%Cefixime, 40.27\%ceftriaxone, 48.61\%Kanamycin 23.6\%Ciprofloxacin, $23.6 \%$ Nalidixic Acid ,18.05\%Aztreonam, 15.27\%Norfloxacin,9.72\%Amikacin, 
0\%Imipenen و واظهرت العزلات مقاومة متعددة ومختلفة لللمضادات الحيوية وموشر مقاومة متعدد يتراوح مابين 0.2- 0.8 وكذللك بينت الدراسة ان غاليبة العزلات تحمل بلازميدات ذو اوزن جزيئة

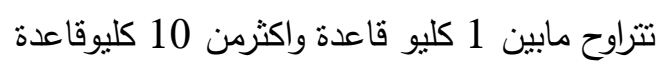

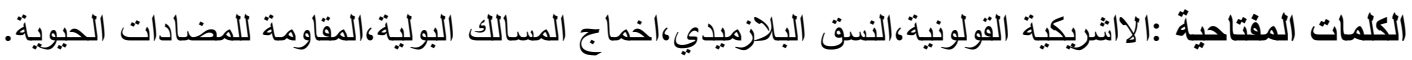

\section{Introduction}

Urinary tract infection(UTI) are the most common of all infection and can occur at any time in the life of individual[1].It is an infection caused by the presence and growth of microorganisms anywhere in urinary tract, it is usually due to bacteria from the digestive tract which climb the opening of the urethra and begin to multiply to cause infection[2-3].In contrast to men, women are more susceptible to UTI, and this is mainly due to short urethra ,absence of prostatic secretion,pregnany and easy contamination of the urinary tract with fecal flora[4].Urinary tract infection is a common bacterial disease, often contributes to frequent cause of morbidity in outpatients as well as hospitalized patients[5].The most important cause of UTI represented by gram negative bacteria belong to Enterobacteriacea family specially Escherichia coli [6].It is accounting for $65 \%-90 \%$ of urinary infection [78].E.coli can be classified into one of three groups: commensal (non pathogenic) E.coli strains that coexist with the host without causing overt disease ,intestinal pathogenic(diarrh-eagenic)E.coli , and extra intestinal pathogenic E.coli (ExPEC).The latter category ,ExPEC, was proposed in 2000 to classify E.coli isolated capable of causing disease outside of the intestinal tract ,including uropathogenic E.coli (UPEC),sepsis-associated E.coli and neonatal meningitis-associated E.coli [9]. Treatment of UTIs cases is often started empirically and therapy is based on information determined from the antimicrobial resistance pattern of the urinary pathogens [10].

However, a large proportion of uncontrolled antibiotic usage has contributed to the emergence of resistant bacterial infection [11-12].As a result, the prevalence of antimicrobial resistance among urinary pathogens has been increasing worldwide. Associated resistance, i.e. the fact that a bacterium resistance to one antibiotic is often much more likely to be resistant to other antibiotics drastically decreases our chances of getting a second empirical attempt right [13]. The development of E.coli resistance to older agents such as ampicillin and trimethoprimsulfamethoxazol as well as the emerging problem of fluoroquinolone resistance, may substantially limit our antibiotic choices [14] . E.coli had a wide range to resist antibiotic due to it has some of genetic factors that able it to resust these antibiotic ,such as plasmids [15]. Which can transfer between genera and species of bacteria lead to prevalence the resistance by conjugation and transformation [16]

\section{Materials And Methods Isolation of Bacteria}

A total 72 E.coli strains were isolated from urine samples .The samples were collected between September 2012 to January 2013 from inpatients as well as the outpatient department of Al-Medina General hospital, Basra General hospital and Al-Shefia General hospital. The midstream urine sample collected from all patients .A stander loop technique was used to place 0.01 $\mathrm{ml}$ of urine on McCaskey's agar(Lab M,UK)and blood agar (Himedia,India ).Bacteria were cultured on these media in aerobic conditions at $37 \mathrm{C}$ for 24 $\mathrm{h}$ and colony count was performed, More than 10 colonies per $\mathrm{ml}$ of urine were considered significant[17]. While count less then that were taken as not significant. The colonies were identified by stander biochemical test according to [18] and by the API20E system (BioMerieux, France). 


\section{Antibiotic susceptibility testing}

Antimicrobial susceptibility testing of the isolates was performed via the Kirby -Bauer disc diffusion technique on Mueller-Hinton agar to determined the antibacterial activity of 20 antibiotics [19] Ampicillin (10mg), Aztreonam (30mg), Norfloxacin](10mg) Augmentin (30mg)

Ceftriaxone (30mg) Amikacin (10mg), Kanamycin (30mg) Cefazolin (30mg) NalidixicAcid (30mg) Chloramphenicol (30mg)Imipenen (10mg) Ciprofloxacin (5mg) Nitrofurantin(300mg)Cotrimoxazol(25mg) Cefoxiti

(30mg)Piperacilin(100mg)Tobramycin(10mg)

$$
\text { Cefepime (30mg) Gentamicin (10mg) }
$$$$
\text { Cefixime(30mg) }
$$

\section{Plasmid DNA extraction}

A total of $67(93 \%)$ multidrug resistant isolated of E.coli are selected for plasmid extraction plasmid DNA was extracted by a stander method then estimated by spectrophotometric Plasmid extraction was carried out by using Kit Pure Yield plasmid Miniprep System (Promega USA)

Electrophoresis analysis of the plasmid DNA Agarose gel electrophoresis for plasmid DNA of multidrug resistant isolated of E.coli was carried out on $1 \%$ agarose gel (promega, USA), in TAE buffer for $4 \mathrm{hr}$. Plasmid DNA bands were viewed by fluorescence of band ethidium bromide under a short wave ultraviolet light trans illuminator and the photograph were taken using a digital camera . The plasmid DNA bands were matched with those for DNA Ladder (Bioneer.korea) molecular weight marker in the range 500-10200 bp

\section{Results}

A total of 306 urine sample were collected and cultured, only 137 sample give positive growth, and only 72 sample identified as E.coli strain table (1). According to their growth morphology and biochemical reaction patterns such as Indol production, methyl red test, vogesproskaure,citrate utilization test ,oxidase test, motility, Urease test.

Table (1) Frequency of E.coli and other bacteria from urinary tract infection

\begin{tabular}{|c|c|c|c|}
\hline $\begin{array}{c}\text { No.of } \\
\text { samples }(\%)\end{array}$ & $\begin{array}{c}\text { No.of positive growth } \\
(\%)\end{array}$ & $\begin{array}{c}\text { No.of E.coli } \text { strain } \\
(\%)\end{array}$ & Others (\%) \\
\hline 306 & $137(44.77 \%)$ & $72(52.55 \%)$ & $65(47.44 \%)$ \\
\hline
\end{tabular}

\section{Antibiotic susceptibility test:}

All the seventy two E.coli isolates were tested in vitro to determine their antibiotic susceptibility patterns by antibiotic disc diffusion ,the results show in table(2).All the isolates (100\%) were resistant to Ampicillin, While ,cefazolin show resistance $(93.05 \%)$, Augmentin (83.33\%), Nitrofurantion (70.83\%), Cefixime (63.88\%),Piperacillin (62.5\%), Kanamycin(48.61\%) Cefepime (4305\%), Ceftriaxone (40.27\%), Tobramycin (36.11) ,Cotrimoxazole(25\%), Nalidixic Acid(23.6\%),Ciprofloxacin(23.6\%), Aztreonam (18.05),Norfloxacin(15.27\%), Amikacin(9.72\%), Gentamicin (8.33\%) ,Chloramphenicol (5.55\%)
,Cefoxitin(1.38\%), and there was no resistance found to Imipenen only .This antibiotic the most effective against E.coli isolated from urinary tract infection 
Table (2): Susceptibility of clinical isolates of E.coli to different antibiotics

\begin{tabular}{|c|c|c|c|c|c|c|c|}
\hline Antibiotic & Abbreviate & Resistans & $\%$ & Intermediate & $\%$ & Sensitive & $\%$ \\
\hline Ampicillin & $\mathrm{AM}$ & 72 & 100 & 0 & 0 & 0 & 0 \\
\hline Aztreonam & ATM & 13 & 18.05 & 19 & 26.38 & 40 & 55.55 \\
\hline Norfloxacin & NOR & 11 & 15.27 & 0 & 0 & 61 & 84.72 \\
\hline Augmentin & AMC & 60 & 83.33 & 12 & 16.66 & 0 & 0 \\
\hline Ceftriaxone & $\mathrm{CRO}$ & 29 & 40.27 & 5 & 6.94 & 38 & 52.77 \\
\hline Amikacin & $\mathrm{AK}$ & 7 & 9.72 & 27 & 37.5 & 38 & 52.77 \\
\hline Kanamycin & $\mathrm{K}$ & 35 & 48.61 & 14 & 19.44 & 23 & 31.92 \\
\hline Cefazolin & $\mathrm{CZ}$ & 67 & 93.05 & 5 & 6.94 & 0 & 0 \\
\hline NalidixicAcid & NA & 17 & 23.6 & 3 & 4.16 & 52 & 72.22 \\
\hline Chloramphenicol & $\mathrm{C}$ & 4 & 5.55 & 0 & 0 & 68 & 94.44 \\
\hline Imipenen & IPM & 0 & 0 & 3 & 4.16 & 69 & 95.83 \\
\hline Ciprofloxacin & CIP & 17 & 23.6 & 1 & 1.38 & 54 & 75 \\
\hline Nitrofurantion & $\mathrm{F}$ & 51 & 70.83 & 12 & 16.66 & 9 & 12.5 \\
\hline Cotrimoxazole & COT & 18 & 25 & 17 & 23.61 & 37 & 51.38 \\
\hline Cefoxitin & FOX & 1 & 1.38 & 5 & 6.94 & 66 & 91.66 \\
\hline Piperacilin & PRL & 45 & 62.5 & 13 & 18.05 & 14 & 19.44 \\
\hline Tobramycin & ТOB & 26 & 36.11 & 11 & 15.27 & 35 & 48.61 \\
\hline Cefepime & FEP & 31 & 43.05 & 8 & 11.11 & 33 & 45.83 \\
\hline Gentamicin & $\mathrm{CN}$ & 6 & 8.33 & 4 & 5.55 & 62 & 86.11 \\
\hline Cefixime & $\mathrm{CEF}$ & 46 & 63.88 & 2 & 2.77 & 24 & 33.33 \\
\hline
\end{tabular}

\section{Multiple antibiotic resistances}

From 72 E.coli isolates ,67 isolates showed multiple antibiotic resistance ,Such that ,eight isolates resisted four types of antibiotics. Nine isolates resisted five types of antibiotics. Nine isolates resisted six types of antibiotics. Eight isolates resisted seven types of antibiotics. Seven isolates resisted eight types of antibiotics .Eight isolates isolated resisted ten types of antibiotics. Two isolates resisted eleven types of antibiotics. One isolates resisted twelve types of antibiotics .Three isolates resisted thirteen types of antibiotics. Three isolates resisted fourteen types of antibiotics .Three isolates resisted fifteen types of antibiotics. Only one isolates resisted sixteen types of antibiotic. (table 3) and (table 4) 
Table (3): Antibiogram patterns to multiple antibiotic resistance isolates

\begin{tabular}{|c|c|c|}
\hline Multiplicity & No.of isolates & Patterns of multiple antibiotic resistance \\
\hline 4 & 1 & $\mathrm{AM}, \mathrm{AMC}, \mathrm{CZ}, \mathrm{F}$ \\
\hline 4 & 3 & $\mathrm{AM}, \mathrm{AMC}, \mathrm{CZ}, \mathrm{K}$ \\
\hline 4 & 4 & $\mathrm{AM}, \mathrm{AMC}, \mathrm{K}, \mathrm{F}$ \\
\hline 5 & 2 & $\mathrm{AM}, \mathrm{AMC}, \mathrm{CZ}, \mathrm{K}, \mathrm{F}$ \\
\hline 5 & 1 & $\mathrm{AM}, \mathrm{AMC}, \mathrm{CZ}, \mathrm{F}, \mathrm{CEF}$ \\
\hline 5 & 1 & $\mathrm{AM}, \mathrm{AMC}, \mathrm{CZ}, \mathrm{K}, \mathrm{PRL}$ \\
\hline 5 & 2 & $\mathrm{AM}, \mathrm{AMC}, \mathrm{CZ}, \mathrm{F}, \mathrm{TOB}$ \\
\hline 5 & 2 & $\mathrm{AM}, \mathrm{AMC}, \mathrm{CZ}, \mathrm{F}, \mathrm{PRL}$ \\
\hline 5 & 1 & $\mathrm{AM}, \mathrm{AMC}, \mathrm{C}, \mathrm{FEP}, \mathrm{CN}$ \\
\hline 6 & 1 & $\mathrm{AM}, \mathrm{AMC}, \mathrm{CZ}, \mathrm{K}, \mathrm{F}, \mathrm{TOB}$ \\
\hline 6 & 2 & $\mathrm{AM}, \mathrm{AMC}, \mathrm{CZ}, \mathrm{F}, \mathrm{PRL}, \mathrm{TOB}$ \\
\hline 6 & 1 & $\mathrm{AM}, \mathrm{AMC}, \mathrm{CZ}, \mathrm{F}, \mathrm{PRL}, \mathrm{CEF}$ \\
\hline 6 & 3 & AM,CZ,CRO,PRL,FEP,CEF \\
\hline 6 & 2 & $\mathrm{AM}, \mathrm{CZ}, \mathrm{AK}, \mathrm{K}, \mathrm{F}, \mathrm{CEF}$ \\
\hline 7 & 1 & AM,CZ,CRO,NA,PRL,FEP,CEF \\
\hline 7 & 1 & $\mathrm{AM}, \mathrm{CZ}, \mathrm{K}, \mathrm{CIP}, \mathrm{F}, \mathrm{PRL}, \mathrm{CEF}$ \\
\hline 7 & 2 & AM ,AMC,CZ,CRO,F,PRL,FEP \\
\hline 7 & 2 & $\mathrm{AM}, \mathrm{CZ}, \mathrm{K}, \mathrm{F}, \mathrm{CIP}, \mathrm{PRL}, \mathrm{CEF}$ \\
\hline 7 & 1 & $\mathrm{AM}, \mathrm{AMC}, \mathrm{CZ}, \mathrm{F}, \mathrm{PRL}, \mathrm{CN}, \mathrm{CEF}$ \\
\hline 7 & 1 & $\mathrm{AM}, \mathrm{AMC}, \mathrm{CZ}, \mathrm{F}, \mathrm{PRL}, \mathrm{TOB}, \mathrm{CEF}$ \\
\hline 8 & 1 & AM,AMC,CZ,CRO,NA,FOX,FEP,CEF \\
\hline 8 & 1 & $\mathrm{AM}, \mathrm{AMC}, \mathrm{CZ}, \mathrm{C}, \mathrm{K}, \mathrm{F}, \mathrm{COT}, \mathrm{CEF}$ \\
\hline 8 & 1 & AM , AMC ,CZ ,F ,PRL,FEP,CEF,COT \\
\hline 8 & 4 & AM,AMC,CZ,CRO,PRL,TOB,FEP,CEF \\
\hline 9 & 3 & AM , AMC , CZ ,K ,F ,CIP ,PRL ,TOB ,CEF \\
\hline 9 & 3 & $\mathrm{AM}, \mathrm{CZ}, \mathrm{K}, \mathrm{F}, \mathrm{NA}, \mathrm{PRL}, \mathrm{TOB}, \mathrm{FEP}, \mathrm{CEF}$ \\
\hline 9 & 2 & $\mathrm{AM}, \mathrm{AMC}, \mathrm{CZ}, \mathrm{CRO}, \mathrm{AK}, \mathrm{F}, \mathrm{PRL}, \mathrm{FEP}, \mathrm{CEF}$ \\
\hline 10 & 2 & AM, AMC ,CZ ,CRO, K ,F,PRL,FEP,CEF,ATM \\
\hline 10 & 3 & $\mathrm{AM}, \mathrm{AMC}, \mathrm{CZ}, \mathrm{CRO}, \mathrm{K}, \mathrm{F}, \mathrm{COT}, \mathrm{PRL}, \mathrm{TOB}, \mathrm{CEF}$ \\
\hline 11 & 2 & AM,AMC,CZ,CRO,F ,NOR,NA,CIP,COT,CEF,ATM \\
\hline 12 & 1 & AM,AMC,CZ,CRO,F ,NOR,PRL ,CIP,COT,CEF, FEP,ATM \\
\hline 13 & 3 & AM,AMC,CZ,CRO,F ,NOR,NA,CIP,COT,CEF,PRL, FEP,ATM \\
\hline 14 & 1 & AM,AMC,CZ,CRO,K,F,NOR,NA,CIP,COT,CEF,TOB, FEP,ATM \\
\hline 14 & 2 & $\mathrm{AM}, \mathrm{AMC}, \mathrm{CZ}, \mathrm{K}, \mathrm{F}, \mathrm{NA}, \mathrm{AK}, \mathrm{COT}, \mathrm{PRL}, \mathrm{TOB}, \mathrm{FEP}, \mathrm{CN}, \mathrm{CEF}, \mathrm{ATM}$ \\
\hline 15 & 1 & $\begin{array}{l}\text { AM,AMC,CZ,CRO,K, ,NOR,NA,CIP ,CN ,COT,CEF,TOB, } \\
\text { FEP,PRL,ATM }\end{array}$ \\
\hline 15 & 2 & $\begin{array}{l}\text { AM ,AMC ,CZ ,CRO ,K ,F ,NOR ,NA ,CIP ,C ,COT,CEF,TOB, } \\
\text { FEP,PRL }\end{array}$ \\
\hline 16 & 1 & $\begin{array}{l}\text { AM ,AMC ,CZ ,CRO ,K , ,NOR,NA,AK,CN ,COT,CEF,CIP,TOB , } \\
\text { FEP,PRL,ATM }\end{array}$ \\
\hline
\end{tabular}

Table (4) Multiple antibiotic resistance index.(MAR Index)

\begin{tabular}{|c|c|c|c|c|c|c|c|c|c|c|c|c|c|}
\hline $\begin{array}{c}\text { No.of isolates } \\
\%\end{array}$ & 8 & 9 & 9 & 8 & 7 & 8 & 5 & 2 & 1 & 3 & 3 & 3 & 1 \\
\hline No.of antibiotic & 4 & 5 & 6 & 7 & 8 & 9 & 10 & 11 & 12 & 13 & 14 & 15 & 16 \\
\hline MAR Index & 0.2 & 0.25 & 0.3 & 0.35 & 0.4 & 0.45 & 0.5 & 0.55 & 0.6 & 0.65 & 0.7 & 0.75 & 0.8 \\
\hline
\end{tabular}




\section{Electrophoretic analysis of the plasmid DNA and Plasmid profile}

Electrophoretic analysis of the plasmid DNA prepared was carried out by agarose gel electrophoresis on $1 \%$ agarose, $60 \mathrm{~V} .4 \mathrm{hr}$. Plasmid profiling demonstrated that 54 of 67 isolates have 1 to 7 plasmid bands with sizes ranging from $1 \mathrm{kbp}$ to $>10 \mathrm{kbp}$. The most common plasmid of $>10 \mathrm{kbp}$ was detected in almost all isolated strain (Figure $1)$.

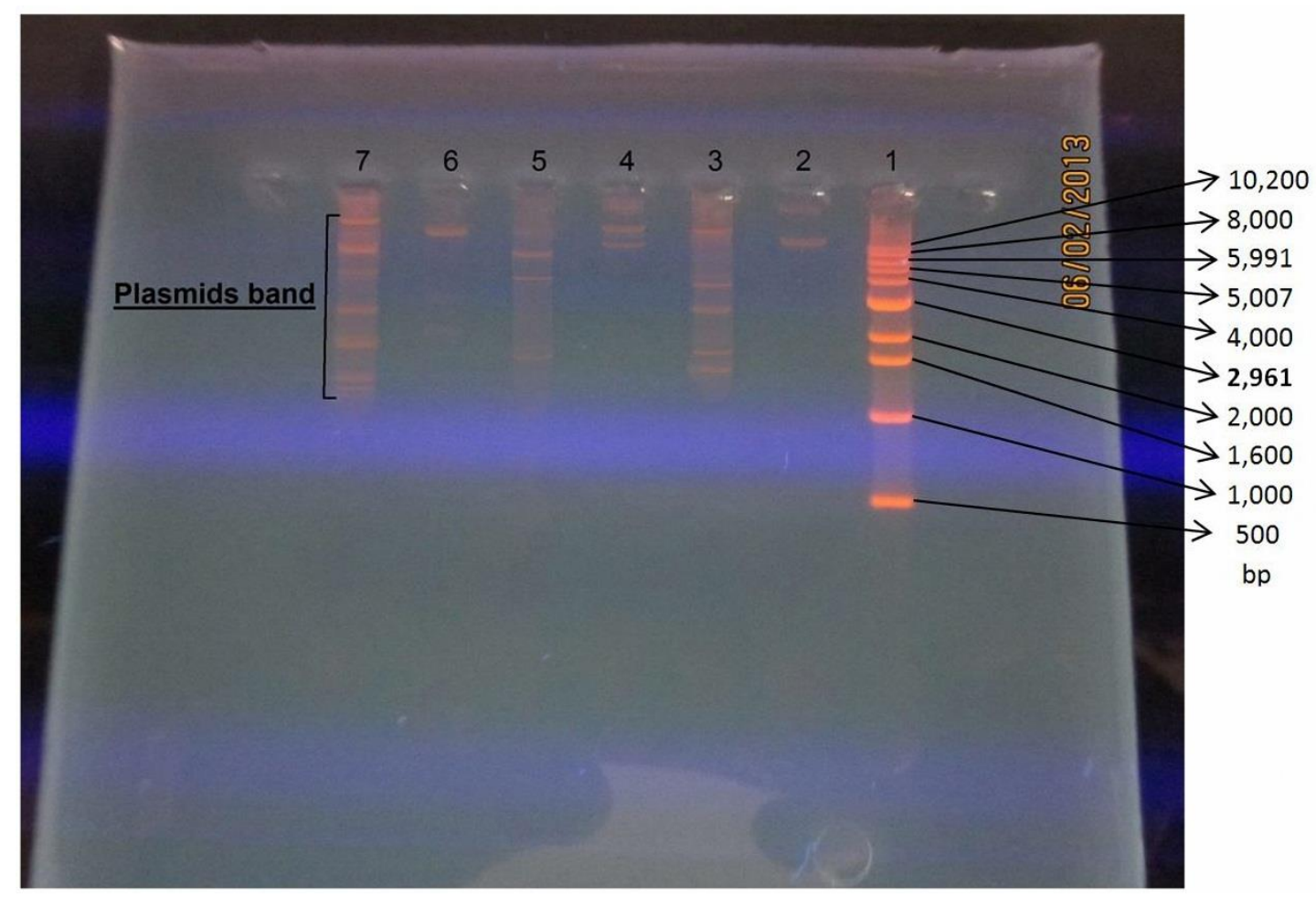

Figure (1) plasmid patterns of some clinical isolated E.coli

\section{Disscusion}

All urine sample were cultured on Blood agar and McConkeys agar ,the rustles of isolation of E.coli from patients with urinary tract infection in this study was 72 isolates(52.5\%).The results agreed with the study done by[20,21,22,23] .E.coli was common agent in patients with urinary tract infection ,the results study agreed with study done by [ 24,25$] \quad$ In this study we observed a high incidence of antibiotic resistance among the isolation of $\mathrm{E}$.coli .Although resistance to ampicillin was high (100\%), cefazolin (93.\%) was the most resistant followed by augmentin (83.3\%) the results study agreed with study done by.[21,24,26]No resistance to imipenem was observed in the studied isolates .A high sensitivity of E.coli strain to imipenem has been previously reported $[27,28,29]$ It seems this antibiotic can serve a medication of choice for the treatment of UTI caused by E.coli. However, it should be noted that unlimited use of a medicine can gradually lead to rising antibiotic resistance. Resistance to nalidixic acid and chloramphenicol in our isolates was lower than that observed in studies performed in other parts of the world[21,30] A high incidence of multidrug resistant (MDR) strains was also detected among the present isolates .A bout 93\% were resistant to 4 or more tested antibiotic. The level of MDR among UTI isolates varies from country to country and resistance patterns of causative uropathogens are vary between regions and countries[31]. For example, it was reported to be $7.1 \%$ in the USA [32], while $42 \%$ of the UPEC isolates in Slovenia in 2006 were MDR[33].The WHO guidelines recommend trimethoprimsulfamethoxazole and ampicillin as the first choice 
for UTI treatment [34] . In contrast, as revealed in the present study, these two antibiotic cannot serve as treatment of choice in our region. The results showed that $55(82.08 \%)$ of the isolates harbored plasmids, other reported results agreed with our study woo-Joo et al.have reported that $87.5 \%$ and $72 \%$ of UPEC strains carried plasmids [35] In another study undertaken by Fluit, the prevalence of plasmid in the isolates was $81 \%$ which was also similar to our results [36] In the present stud, the range of plasmids was 1-7 while Malkawi has reported the numbers of plasmids to be approximately 1-6 in E.coli strains[37] Molecular weights of the plasmids were between 1 - $>10 \mathrm{kp}$. This result was similar to those found in anther study In Turkey Celebi et al. were found molecular weigh of the plasmid between 1-19 $\mathrm{kp}[38]$. On the other hand, $12(17.9 \%)$ of our isolates have no plasmid, yet they were resistant to a large number of antibiotic .possibly ,some antibiotic resistance genes may not be located in the plasmid may be on the bacterial chromosome .In order to prove the relationship between the plasmid and its resistance ,additional studies such as plasmid curing and transferring of the plasmid to other known bacteria should be performed.

\section{$\underline{\text { Conclusions }}$}

This study revealed that urinary tract infection in patients is highly prevalent caused by E.coli ,and there is the prevalence of antibiotic resistant strain which make a problem in treatment urinary tract infection Since urinary tract infection is a nosocomial and community acquired infection , it is recommended that over crowding in the health institution should be avoided to reduce the spread of the infection within the hospital .E.coli isolates are sensitive to imipenem by disc diffusion method ,High percent of isolated E.coli found to be resistant to Ampicillin and cefazolin and Augment that may be due to the irrational use of this antibiotic. The results obtained from electrophoresis analysis and fluorescence of bands under short wave ultraviolet light trans illuminator showed that multidrug resistance mediated by plasmids.

\section{$\underline{\text { References }}$}

Santo,E.;Macedo,C. and M. J.Moacir(2006) .Virulence factors of Uropathogenic Escherichia coli from a university hospital in Ribeiropreto,SauPaulo,Brazil.Rve.Inc Med .Trop. S. Paulo. 48:185-188

Rahimkhani M, Khavari-Daneshvar H, Sharifian R (2008). Asymptomatic bacteriuria and Pyuria in pregnancy. Acta Med. Ranica. 46:409-412

Okonko IO,Ijandipe LA,IIusany OAet al (2009).Incidence of urinary tract infection (UTI) among pregnant Women in Ibadan, South Western Nigeria. Afr J Biotechnol. 8:6649-6657

Haider G, Zehra N, Afroze Munir A, Haider $A(2010)$. Risk factor of urinary tract infection in pregnancy .J Pak Med Assoc. 60 :213-216

Wagenlehner FM, Naber KG( 2006). Treatment of bacteria urinary tract infection: presence and future. Eur Urol. 49:235-244

Usein ,C.R,;Damian , M. and D Tatu-Chititu(2001) .Prevalence of virulence gene in Escherichia coli strain isolated from Romanian adult urinary tract infection cases .Cell Med. 5:303-310

Schlager TA (2003).Urinary tract infection in infants and children .Infect Dis Clin North Am:353-356

Gupta K(2003). Emerging antibiotic resistances in urinary tract pathogens .Infect Dis Clin North Am :17:243-259

Russo, T. A., and J.R. Johnson .Proposal for a new inclusive desig-nation for extra intestinal Pathogenic isolates of Escherichia coli :ExPEC. J.Infect.Dis .181:1753-1754

Wilson ML (2004). Gaidio Laboratory Diagnosis of urinary tract infection in Adult patients Clin Infect Dis 38:1150-1158

Bonadio M, Meini M, Spetaleri P, Gilgi C(2001). Current microbiological and clinical aspects of urinary tract infections. Eur J Urol.40:439445. 
Kripke C (2005).Duration of therapy for women with uncomplicated UTI .AM Fam Physician7:543-547

Sundqvist M, Kahlmeter G(2009). Pre-emptive culturing will improve the chance of getting it right when empirical therapy of urinary tract infection fails .J Anti. Ch. 64:226-228

Karlowsky JA, Kelly LJ, Thornsberry C, Jones ME and Sahm DF. Trends in antimicrobial resistance among urinary tract infection isolates of Escherichia coli from female outpatients in the United States .Antim. Ag. Ch . 2002.46:2540-2545.

Brooks. F.Geo, Karen C.Carroll ,Janet S.Butel, Stephen A. Morse, Timothy A. Mietzner(2010). Medical Microbiology. International Edition 25thed McGraw-Hill books .;

Dionisio, F,; Matic , I.;Radmab, M.; Radriques, O.R. and Taddi ,F(2002). Plasmids spread very fast in heterogeneous bacterial communities .J Gen .; 162:1525-1532

Forbes,B.A.;Sahm,D.F.and Weissfeld,A .S(2007). Bailey and Scotts Diagnostic Microbiology, international edition, 12th ed ., Mosby year Book Inc.,USA.

MacFaddin JF .Biochemical tests for identification of medical bacteria, Lippincott William \&Willkins, Philadelphia USA.

Bauer AW, Kirby MM, Sherris JC, Turch M(1996). Antibiotic susceptibility testing by standardized single disc method .Am.J.Clin.Path .;36:493-496

Sarpong.C.K.G ,Edwin M.T.Y,Ali.I,Addae A.A,Ken A, Roland .A ,Yaw A.B,Annan A.A. (2012) Bacterial Urinary Tract Infection among Males with Lower Urinary Tract Obtruction at Komfo Anokye Teaching Hospital ,Kumasi, Ghana.Open J. Urol;2:131-136.

Al-Tememi .Lina A., Reham M.Al-Mosawi, and Mohamed A. Al-Ali(2011). Study the prevalence of some urinary tract bacterial pathogens. Journal of education of college,; $4: 25-35$
Chenari Mohsen R, Shahram Gooran, Amin Zarghami, Faramarz Fazeli (2012). Assessment of Urine Analysis Diagnostic Role: A Cross-Sectional Study in South Eastern of Iran.Open J Urol. 2:227-231.

Abdullah .Essam.M, Saad T.Mutlak(2009).The incidence of Lower (UTI) according to the age and sex in Ramadi City.J Fac Med Baghdad.51:289-291.

Zayed .M.E, Suliman, A. A, Inas M. M. ; and Reda A .A. (2013).Assessment of bacteria as virulence agents for urinary tract infection in Egyptian patients,Afr.J.Microbiol.Res. 14:1278-1285.

Khan, S. A., Feroz, A.; Noor,R.(2013).Study of extended B-lactamase -producing bacteria from urinary tract infections in Bangladesh .Tzu Chi Med. J. 25:39-42.

Fredrick F., Joel M.F., Maulidi ,F and Samuel Y.M(2013). Aetiology, antimicrobial susceptibility and predictors of urinary tract infection among febrile under -fives at Muhimbili National Hospital, Dar es SalaamTanzania.Afr.J.Microbiol.Res. ; 12:10291034

Mathai E, Grape M,Kronvall G.Intergrons and multidrug resistance among Escherichia coli causing community acquired urinary tract infection in southern India(2004). AP MIS. 112:159-164

Japoni A,Gudarzi M,Farshad SH,Basiri E,Ziyaeyan M,Alborzi A,et al(2008). Assay for intergrons and pattern of antibiotic resistance in clinical Escherichia coli strain by PCR-RFLP in Southern Iran Jpn.J Infect Dis.;61:85-88

Gulsun, S.;Oguzoglu, N.;Inan A,Ceran, N. (2005).The virulence factors and antibiotic sensitivities of Escherichia coli isolated from recurrent urinary tract infection. Saudi Med. J.;26:1755-1785

Dharmishtha, G.T.;Gandhi, P. J .;Patel Kiran, N 2012.A study on antibiotic related resistance in UTI patients : A comparison between community acquired and hospital acquired E.coli .National J. comm. Med..2:255-258 
Schito, G.C.;Naber, K.G.;Botto, H.Palou, J.Mazzei, T.;Gualco, L.et al(2009).The ARESC study :an international survey on the antimicrobial resistance of pathogen involved uncomplicated urinary tract infection .Int $\mathbf{J}$ Antimicrob Agents.;34:407-413

Linder, J.A; Huang, E.S.; Steinman, M.A.; Gonzales, R.; and Stafford, R.S.(2005). Fluoroquinolone prescribing in the United States: 1995 to 2005. Am. J.Med.2005; 118:259-269.

Rijavec, M.; Starcic Ergivec, M. ; Ambrozic Augustin, J. ; Reissbrodt, R.; Fruth A,Krizan -Hergouth V,et al(2006) .High prevalence of multidrug resistance and random distribution of mobile genetic elements among uropathogenic Escherichia coli (UPEC) of the four major phylogenetic groups. Curr. Microbiol .;53:158-162.

Wolff, O.;Maclennan, C.(2007). Evidence behind the WHO guidelines hospital care for children:What is the appropriate empiric antibiotic therapy in uncomplicated urinary tract infection in children in developing countries J. Trop. Ped .;53:150-152.

Woo-joo, K;Hee-Lin, J.;Hyun, J. P;Min-Ja, K.Seung -Chull, P.(1995).Application of ribotyping for molecular epidemiology study of Escherichia coli isolated from patient with urinary tact infection .Kor $\mathbf{J}$ Infect Dis.;27:505-517

Fluit, A.C; Janes, M.E. (2001) Antimicrobial resistance among UTI isolates in Europ.Antonie Van Leeuwenhock. 77:147152.

Malkawi, H.I.; Youssef, M.E(1998). Antibiotic susceptibility testing and plasmid profile of Escherichia coli isolated from diarrheal patients .J Trop Ped.;44:128-132.

Celebi,A.;Duran,N.;Ozturk,F.;Acik,L.;Aslan,G.and Aslantas, O (2007). Identification of clinic uropathogen Escherichia coli Isolates by antibiotic susceptibility ,plasmid and wholeCell protein profiles.Adv. Mole. Biology, 1:31-40 